\title{
THE ALTERNATE DISPUTE RESOLUTION MOVEMENT: WAVE OF THE FUTURE OR FLASH IN THE PAN?
}

\author{
HOWARD R. SACKS*
}

\begin{abstract}
The author discusses the Alternate Dispute Resolution movement and the alternate methods it advocates.
\end{abstract}

\section{INTRODUCTION}

John A. Weir, whose memory we honor tonight, was born in the American midwest, in Ardock, North Dakota. I, too, am a son of the American midwest, having been born and raised in Sioux City, Iowa. Dean Weir went north; I went east. But our paths cross here tonight, and I can ony hope that my remarks would have satisfied his high standards of learning and scholarship.

My talk tonight on the alternate (or alternative) dispute resolution movement (ADR) will be divided into six parts: (1) Why the interest in ADR; (2) The various forms of alternate dispute resolution; (3) The goals of an optimum method of resolving disputes; (4) Evaluating some typical ADR programs; (5) ADR and the individual lawyer. Finally, the future of $A D R$, and whether it is likely to be the wave of the future or only a flash in the pan.

\section{WHY THE INTEREST IN ALTERNATE DISPUTE RESOLUTION?}

The quest for new methods of resolving disputes is due to the current (but not unprecedented) unhappiness with the judicial process. That process, in the eyes of many participants and observers, now means excessive delay; high expense; and less than optimum results.

As to delay, I can tell you that, in the federal courts throughout the United States, the period from filing to trial in civil cases now averages one and one-half years. For some litigants, that is too long to wait. In my home city of Hartford, Connecticut, a simple personal injury suit will take from one to one and one-half years from filing to trial. Moreover, if the case is a complex one, and a jury trial is demanded, it will take from three and onehalf to four years to bring the case to trial. For many litigants such delays are absolutely intolerable.

As to expense, let me say a few words about the Texaco-Pennzoil dispute, about which many of you have undoubtedly read. Texaco has spent, by November of this year, 60 million dollars in legal fees. Moreover, because Texaco is in bankruptcy, it must pay the legal expenses for creditor and shareholder committees; these expenses run to about 22 million dollars per year.

But it is not just the big corporations paying out millions in legal expenses. Suppose that you live in my city of Hartford, and you need a lawyer. Unless you can secure one on the basis of a contingency fee, which

\footnotetext{
* Professor of Law, University of Connecticut Law School.
}

(Edited text of Weir Memorial Lecture, delivered on November 30, 1987, at University of Alberta Law Faculty). 
is often impossible, the charges for an associate in a medium-size law firm will cost you $\$ 500$ per day. If you want a partner to help you with your case, you will pay $\$ 1000$, or more, per day.

I put it to you: what does the middle-income individual or the small businessman do, if he or she has a dispute with the government or with a big company, and needs a lawyer?

As to the results of litigation, there is also unhappiness. One problem is that court litigation may not deal with the underlying problems in the dispute, but only the legal issues, and thus will fail to solve that underlying problem. For instance, a dispute between two neighbors over a barking dog, when it gets to court, will often get narrowed down to the question of whether the owner violated a municipal noise ordinance. Yet, this legal question may be only the tip of the iceberg; there may be a history of years of petty disputes between the neighbors. What is needed is some process of dealing with the relationship; the judicial process in some overworked municipal court will often fail to come to grips with that fundamental problem.

The judicial process, especially when it results in a trial, may also increase friction and animosity between the parties - a bad result - if the parties must continue to have a relationship. A good illustration: a divorce case involving minor children and a fight over child support, custody, and visitation.

\section{THE FORMS OF ALTERNATE DISPUTE RESOLUTION.}

There is a bewildering array of types of ADR, and often the title of a particular program is misleading. For example, a "mini-trial" is not really a trial but rather a special form of negotiation. On the other hand, the term "mini-trial" is sometimes used in place of the more familiar term, "summary jury trial", which is a trial. So I shall spend a little time describing for you some typical forms of ADR. I shall make special reference to ADR programs in my home state of Connecticut.

Some forms of ADR are run by the parties themselves, e.g. private arbitration. Everyone here surely knows about arbitration, which has been around for hundreds, if not thousands, of years. You're aware of the use of arbitration in labor disputes, construction disputes, and commercial disputes. There is wide, and increasing use of arbitration in the U.S., for instance, in consumer disputes, and in cases involving uninsured motorist coverage under automobile insurance policies. There is even some use of mandatory arbitration, that is, arbitration required by law. In my state, for instance, disputes between public sector unions, such as municipal workers, and their governmental employers over the terms of new contracts, must be arbitrated, if the parties cannot reach an agreement by themselves. Arbitration, of course, is also used here in Canada.

Mediation, as most of you already know, is different from arbitration, although many persons confuse these very different forms of ADR. In arbitration, the third-party neutral decides the case, just like a judge. In mediation, the third party neutral helps the parties to achieve a settlement of the case. Although the mediator may make suggestions for resolution of the dispute, he has no authority to impose it on the parties. 
Mediation has been around for thousands of years; its first use, and it is still being used, is in the family. When mother or dad must cope with a dispute between Kate and Lucy, the parent often tries to help the children settle the dispute themselves, instead of directing what is to be done.

In the United States of today, mediation is widely used in labor disputes, especially in disputes over the terms of employer-union contracts. Mediation is spreading into other areas, such as domestic relations disputes note the increasing use of divorce mediation; disputes between neighbors - note the neighborhood justice center movement; and even into environmental disputes.

However, there are newer forms of ADR, some with fancy names. One of these is the mini-trial, which is not really a trial, but a new form of negotiation. It usually involves two corporations, involved in a big dispute with a lot of money at stake. A high official of each disputant - perhaps the CEO - meets with his counterpart, and they listen to lawyers from each side present abbreviated versions of their claims and defenses, usually without live witnesses. At this informal hearing, there may or may not be a neutral presiding officer. After this presentation, the two corporate officers retire by themselves, and try to negotiate a settlement. They take into account not only their respective chances of winning, and the costs of going forward, but such factors as the need to maintain good relations with the other side.

So the mini-trial is not a trial but rather a structured form of negotiation, or, as it is sometimes called, an "information exchange." The mini-trial has achieved substantial acceptance among many large corporations, which prefer it to spending huge amounts of money - and time - in a conventional law suit.

I should add at this point that ADR is being used not only in disputes between private parties, but in disputes between governmental units and private parties.

Some of the new forms of ADR are being conducted under auspices of the courts; it's public alternative dispute resolution. For instance: courtannexed arbitration is being tried in many places. In this form of arbitration, the court encourages, or forces, disputing parties to take their case to a court-appointed arbitrator. "Arbitration" is perhaps a misnomer, because the decision of the arbitrator is usually not binding, but merely advisory, and thus the parties are free to disregard his "decision" and proceed with normal litigation procedures, including trial and appeal. In Connecticut, court-annexed arbitration has been tried, in both state and federal courts, and appears not to have worked very well. However, this form of public ADR is being experimented with in other parts of the country, and we don't know at this time whether it will be successful.

Let me now mention two other forms of court-controlled (public) ADR. We in Connecticut have a trial referee program, in which the judges appoint experienced lawyers to act as referees in non-jury cases. We, in common with many other places, also have summary jury trials, which may be described as mock jury trials, involving real disputes, with the jury rendering an advisory verdict. I shall discuss and evaluate these two forms of ADR in some detail very shortly. 
Before doing that, however, I must outline a set of goals or criteria for analyzing any kind of dispute resolution mechanism. I am sure that you agree that we cannot tell whether any form of ADR is successful unless we first have some criteria for evaluation.

\section{THE GOALS OF AN OPTIMUM SYSTEM OF DISPUTE RESOLUTION}

1. Availability of the particular dispute resolution mechanism to all who need it. In other words, affordable, easy access.

2. Speed of disposition of the dispute.

3. Low cost.

Another way of saying that we want speedy and inexpensive procedures is that we want finality. We want a relatively quick decision, which will be final, and which won't cost the disputants, or the state, large amounts of money. Thus, any dispute resolution mechanism which permits an appeal, or multiple appeals, runs up the costs and creates delay.

4. Private or public procedure. Sometimes, parties want privacy for resolving their dispute. On the other hand, one or both parties - or the public - may prefer a procedure open to public scrutiny.

5. Justice. We want just results from the process, both in terms of a sound solution to issues of liability, and of adequate remedies for breach of any legal duty. To achieve this goal, we must satisfy some sub-goals:

a. Often, representation by counsel will be necessary. After all, lawyers are specialists in marshalling evidence, discovering relevant theories, and presenting coherent arguments to the tribunal, whether it be a judge, jury, administrative agency or government officer.

b. Procedures for adequate development of the record. Often, not just a hearing, but pre-hearing procedures, such as pleadings and discovery, will be required.

c. Competent and impartial decision makers.

d. Appeal rights, to correct the inevitable errors of even the best decision makers.

6. Obedience to decisions. We want the loser to comply quickly with the decision; we don't want to spend money on, or drag out, compliance.

7. Guidance to the parties, and others in similar situations, as to future conduct. This will be especially important if the parties to this dispute will have a continuing relationship. In practical terms, this often will require a reasoned opinion, and not just a decision.

8. Improving the ability of the parties to resolve any future disputes. Put another way, we may want to use the process for resolving this dispute to improve the skills of the parties to resolve their own disputes.

9. Reduction of conflict and animosity between the parties; producing a more harmonious relationship.

You'll see in an instant that these goals conflict among themselves. For instance, the goal of finality - with its emphasis upon speed and low cost - may well conflict with the goal of justice. For achieving justice may require developing a full record, and appeal rights, both antithetical to the goal of finality. Similarly, guidance to the parties usually means an 
opinion, and requiring the decision-maker to write an opinion will run up costs and create delay.

This is the root of our problem. We can't have everything we want. Your Prof. William Hurlburt, in his talk to the Canadian Bar Association last year, made this same point. I commend his talk to you.

Another way to state our dilemma: the price of perfect justice may be too high. A full-dress judicial proceeding, complete with pleadings, discovery, jury trial, and right of multiple appeals, may produce a more just result than an arbitration. But the cost in time and money may be exorbitant, and indeed, some persons may be priced out of the court system altogether because they can't afford the money required to carry on such a proceeding.

\section{EVALUATING SOME TYPICAL ADR PROGRAMS}

It's important to evaluate ADR, especially for Americans, who tend to embrace new ideas with enthusiasm, and often without sufficient thought. My evaluation will be in terms of the aforementioned goals of a sound system of dispute resolution. This evaluation will, I trust, serve two purposes. First, a public perspective. By that, I mean, should courts and legislatures and the organized bar promote, support and use ADR? A second reason for this evaluation has a private perspective, that is, whether individual lawyers, representing clients, should initiate or use ADR mechanisms.

It is, of course, impossible for me to evaluate all the many forms of ADR. Instead, I shall select a few, and hope that the questions I ask will help you evaluate the particular ADR mechanisms which you will encounter. I shall begin with the summary jury trial.

\section{A. SUMMARY JURY TRIAL}

The summary jury trial was pioneered by a Federal judge in Ohio, Thomas Lambros. What is it? A real jury is selected, although it may be smaller than the normal jury; there is a real judge; and there is a presentation by lawyers to the judge and jury. However, this presentation is limited to a few hours or perhaps one day. The presentation combines facts and legal argument; the factual statements are to be based upon depositions or stipulations. The jury then receives instructions from the judge in the usual manner, and it retires to deliberate. It brings back a verdict, both as to liability and damages. This verdict, of course, is not binding. But the theory of the summary jury trial is that the parties, having been apprised of what a real jury might do, will find it easier to settle, thus saving the delay, expense and uncertainty of continuing the litigation until jury.

Judge Lambros is enthusiastic about his brain child. He reports that, of 153 cases he submitted to the summary jury trial process, only five continued through to jury trial. This is only three $\%$. The other $97 \%$ were settled or withdrawn without jury trial. Says the Judge: these figures prove that this ADR procedure is a success.

I think his analysis is a bit superficial, and I want to dig deeper. (I am aware that Canada makes little use of the jury in civil cases, but I hope that my analysis will nonetheless be helpful as an example of how one might go 
[VOL. XXVI, NO.2

about evaluating an ADR experiment.)

We know that the overwhelming majority of cases filed, perhaps 90 or $95 \%$, never get to trial. They are disposed of by dismissal, withdrawal or settlement. Judge Lambros refers a case for summary jury trial only after motions to dismiss and motions for summary judgment have been decided, and after judge-conducted settlement conferences have been held. Many, many cases are disposed of in this initial screening process.

Of the cases left, what percentage, under normal circumstances, will still go to trial? Certainly not all; a number will be withdrawn or settled, sometimes on the courthouse steps. We need to know the percentage of cases surviving the initial screening process which will actually go to trial. This will be our control group, against which we can judge the success of the summary jury trial procedure.

Judge Lambros doesn't tell us the size of this normal (control) group. My estimate - and it is only a bit better than a guess - is from 14 to $28 \%$. That is, of the cases which survive the initial screening process, from 14 to $28 \%$ will be tried; the balance will be settled or withdrawn.

Judge Lambros' figure for his experimental group is 3\% (five out of 153). If we had a reliable estimate for the control group, we could then compare the two, and test for statistical significance. For instance, if $\mathbf{2 8 \%}$ of the normal group eventually get to trial, and the summary jury trial reduces this to $3 \%$, it is likely that something significant is going on. If, on the other hand, the figure for the control group is only $14 \%$, we need to be more cautious about drawing conclusions.

In any event, even if using the summary jury trial significantly reduces the number of cases having to be tried, we must ask other questions - in light of the goals of an optimum system of dispute resolution - before we can pronounce it a success.

Did the cases referred to summary jury trials settle more quickly than those which would have settled anyway? If not, nothing has been gained in the way of speedier justice. Of course, those cases which only the summary jury trial was able to settle almost surely were disposed of earlier than if they had to wait for a jury trial, and perhaps for an appeal as well.

Was money saved? It is hard to know. After all, the summary jury trial itself consumes resources: lawyer time, judge time, jury time, client time. Not so much as would a full-fledged trial, but still something. We must compare the cost of cases "saved from trial" (number of cases times the cost of a typical jury trial) with the cost of all the summary jury trials (number of cases times cost per case). While a summary jury trial is probably less costly than a regular trial, what of those cases which did not settle after the summary jury trial (3\% of cases referred)? Those cases incurred double costs: the cost of the summary jury trial, plus the cost of a normal trial. It is clear that we need more data.

What about the justice of the results achieved through settlement by means of the summary jury trial? Perhaps we can assume that cases which would have settled anyway would not be very much different in result than those same cases settled after the summary jury trial. But what about the additional cases which settled because of the summary jury trial, and which ordinarily would have gone to trial? Were the results reached through 
settlement as fair and just as those which would have been reached through trial?

A very difficult question to answer, I grant you. But we should at least ask it. Can we use party satisfaction with the results as a proxy for justice? Might we ask the judge who presided over the summary jury trial to compare, in terms of justice, the result actually reached through settlement with that likely to have occurred in a real trial? Would it be worthwhile to ask this same question of counsel for the two parties?

Another troublesome problem is what I call the paradox of a successful dispute resolution procedure. If a particular procedure reduces the incidence of subsequent steps in the process, it may be worth using subject to the caveats on cost saving, justice, etc., discussed above. Thus, the case for the summary jury trial is that it reduces the number of trials. However, introducing a new element into the process may affect prior steps as well, and with detrimental effects. In our case, the availability of the summary jury trial might induce either or both parties to refrain from settlement at an early stage of their dispute, in the hope that waiting for a summary jury trial might yield a more favorable settlement. Thus, fewer cases might settle at early stages of the process, with adverse effects on speed and cost. Does this occur when we use the summary jury trial? Even if it does, do the benefits of saving jury trials outweigh the costs of postponing settlements normally reached at early stages in the process? I have neither data nor guesses; all I can say is that we need to ask and answer these questions before we can be confident in making a judgment about the summary jury trial.

Finally, what worked in Ohio (if indeed it did work) may not work in the Connecticut or California federal courts, not to mention the state courts in these jurisdictions. In short, a successful experiment needs to be repeated before we can draw any conclusions about its general applicability.

I do not wish to be understood as saying that the summary jury trial is a failure. I am only arguing that we need to know much more than we do before deciding whether this type of ADR meets enough of the goals of an optimum system of dispute resolution to justify continued use and expansion.

\section{B. ATTORNEY TRIAL REFEREE PROGRAM}

Let me now turn to another ADR project, once again a part of the judicial process, Connecticut's attorney trial referee program. This program, involving the use of practicing lawyers as trial referees, is run by the state courts. You may find my description of the program of particular interest, since, so far as I know, Canada is not using members of the bar as judicial decision-makers.

The referees are experienced lawyers, and their jurisdiction is limited to non-jury cases (bench trial cases), involving claims of more than $\$ 15,000$. The referee conducts a regular trial, and the loser can appeal to the trial court for relief from the referee's decision. In the strict sense, therefore, the referee's decision is not binding. Moreover, party consent is required for referral of a case to a trial referee. 
This program has been running for nearly four years, and has been studied by an independent agency, the National Center for State Courts. Thus, we have better data than is available for summary jury trials. The results of the study make the program look good, but, in my view, it is still too early to tell whether the program will make a permanent contribution to the problems of judicial backlog and delay.

Many cases go to trial referees, and the decisions of trial referees are almost always accepted by the parties. Thus, our goal of finality is being achieved. As a result, many cases are being disposed of by trial referees, and many bench trials need not be held. Consequently, the program has been a factor, although not the only factor, in reducing the backlog of civil cases. To be specific, the backlog was cut from 10,000 to 3600 in a 45month period. Moreover, the trial referee program has also played a part in reducing delay, specifically the time for disposing of a case, once it has been placed on the trial list. My estimate is that it has cut disposition time, measured between those two points, by about four months.

How about cost? To date, this has been a very inexpensive program, since the lawyers normally serve as trial referees without compensation. As to other costs, the courthouses are already there, and clerks and other judicial personnel would have to be at a regular trial anyway.

As to the quality of the results reached - the justice factor - there is little to go on. No attempt was made to measure this directly and I concede that it would be very difficult to achieve. We do have the results of a survey of those who used the system. Litigating lawyers, i.e., those who represented clients before trial referees, were asked whether the trial referee system produced "second-class justice", and they said no.

This is encouraging, but clearly not definitive. There is certainly plenty of room for fresh thinking about how to measure the quality of results reached in ADR programs; perhaps some of you will come up with good ideas.

Finally, some of the attorneys serving as trial referees said that they had learned things from their service. It is unclear as to what they learned. If, for instance, they acquired a greater sense of the difficulties in deciding cases, this knowledge, or perhaps more accurately, this attitude, might be passed on to clients, thus increasing party satisfaction with the judicial system, especially among those who lose their cases.

Of course, being a law professor, it would be out of character for me to praise anything in unqualified terms. So let me raise one doubt about this attorney trial referee program. Will it continue to be successful over time if it must depend upon unpaid volunteers? Lawyers are busy people, and the busiest lawyers might be the best trial referees. Of course, we could start paying compensation. Yet, this could run up costs substantially, at least if we were to pay lawyers anywhere near what they are getting in their practices. So it is hard to know whether the program will continue to recruit enough capable judge-substitutes.

\section{DIVORCE MEDIATION}

The third program I want to discuss - but only briefly - is mediation in divorce cases. I know that experiments of this kind are going on here in 
Canada. In Connecticut, in our state courts, we have staff mediators in divorce cases, whose function it is to work with husband and wife in order to reach a settlement, and thus avoid a battle before the judge. However, the jurisdiction of these staff mediators in the family courts is usually limited to custody and visitation issues; they are not empowered to deal with questions of alimony, child support or division of property.

In addition to this form of public ADR in the family law area, we also have a modest amount of private divorce mediation, for which parties pay. These private mediators can mediate all the issues between the divorcing parties. Private divorce mediation is expensive; many divorcing couples can't afford the fees. If parties can afford the fees, and the process results in settlement, there are several potential advantages. The mediation process is private; many divorcing couples would like to avoid publicity. Divorce mediation may save attorneys' fees and it may produce less rancour and bitterness, an important factor if there is to be some kind of continuing relationship, as there will be if minor children are involved.

I have no statistics to offer you, but I can say that mediation conducted under court auspices seems to be solidly established. As to private divorce mediation, I have a serious question to raise, growing out of the fact that the mediators are paid on a per case basis, and do not operate under public supervision.

My concern is over power imbalances between the parties, and the danger that mediators will be unable, or unwilling, to right the balance. Suppose, as is sometimes the case, that the husband is an experienced business man and that the woman is a housewife. Assume that the dispute involves alimony, child support, and division of property. Unless the wife has a competent lawyer, and perhaps an accountant as well, the husband can pull the wool over the wife's eyes as to the value of his stock in a closelyheld corporation, or the value of his pension rights in a large company. The private mediator, unlike a judge or court staff mediator, is unlikely to intervene to insure that all the facts come out. Mediators, after all, are likely to get cases only if they can demonstrate their success, i.e., a high percentage of settlements. So the self-interest of a private mediator is achieving a settlement, and not necessarily a fair settlement.

There is another form of potential power imbalance: experience and skill in negotiation. The business-man husband may be a far better negotiator than the wife, even if she has a lawyer somewhere in the background. Once again, I fear that the private mediator may do nothing to correct such imbalances, and that the result may be injustice under the law.

Indeed, the fact that the process is private raises a larger question: are there not dangers in any private dispute resolution procedures, dangers that a stronger party will harass, intimidate, or overwhelm his weaker opponent? Does this mean that government, with its inevitable bureaucratic approach, must supervise ADR in the private sphere?

\section{SUMMARY}

To summarize what I've said about these particular ADR programs, I put it to you in a phrase frequently used in the U.S.: "the jury is still out." We need more data, more searching questions, and perhaps more experi- 
ence, before we can draw definite conclusions about summary jury trials, attorney trial referees, and private divorce mediation.

A final thought about evaluating the ADR movement. It may be that we need to think more boldly about the problems of access to the courts, and of the delay and cost to those who are able to gain access. Let me raise two fairly radical notions for your consideration.

The first is to expand no-fault auto accident victim compensation programs. In Connecticut, and in other states as well, many automobile tort cases still come to court, because of the limited scope of no-fault programs. Why not raise the ceilings for automatic payments to victims, and the thresholds for going to court, and thus push a large number of these cases out of the courts?

My second suggestion involves the criminal side of court dockets. Criminal cases consume a major portion of judicial resources. Yet, except for the diversion of minor offenses into mediation, (sometimes conducted at neighborhood justice centers), we are not using ADR methods to help cut down the high volume of criminal cases. Would it make any sense to try to increase the number of settlements - plea bargains - by involving the judges in plea negotiations between prosecutor and defense counsel? After all, on the civil side, judges and magistrates do this every day, and with success.

I am aware of the problems involved, such as the legitimation of "plea bargaining", still a dirty word in many quarters. But shouldn't we at least consider the possibility of using judges to increase the number of, or reduce the delay in obtaining, negotiated pleas?

I cannot say much about ADR here in Canada, other than to note the comment by Mr. Justice Allen Linden, President of the Law Reform Commission of Canada, that "Canada is a compromising nation." Perhaps the potential for ADR in Canada is greater than in the United States.

\section{ADR AND THE PRACTICING LAWYER}

My evaluation of American ADR programs is certainly not intended to make you cynical, or even skeptical, about ADR. I merely want to persuade you to be cautious, in your role as citizens and community and bar leaders on the one hand, and practicing lawyers on the other. Let me now say a few more words about the practicing lawyer and ADR, that is, what attitude should the practitioner take toward ADR?

My view is that the lawyer should objectively and carefully examine ADR programs, and, to the extent that he thinks that such programs might help his client, cheerfully participate in them. When in doubt, and unless failure of a particular program would seriously harm his client, he should participate. For instance, the many forms of ADR which involve mediation involve small risks to clients; if the mediation does not produce results satisfactory to the client, he is free to continue litigating. Moreover, we need experimentation, and some risks have to be run if we are to break new paths to the achievement of justice.

I should also point out that the American lawyer has certain ethical obligations, such as the duty to minimize fees, help improve the administration of justice, and aid in expediting litigation, which should predispose 
him toward cooperating in ADR programs. I assume that there are similar obligations under the ethical codes binding Canadian lawyers.

Then, too, there is the matter of lawyer self-interest. Early settlements mean earlier collection of fees, and $\$ 1000$ in the till today may be worth more than the mere chance of collecting $\$ 2000$ three years into the future. Furthermore, clients appreciate a lawyer who can achieve a prompt settlement of a dispute, and who demonstrates a willingness to try new methods to that end. Most clients have no great love of litigation; they want results, and as quickly and cheaply as possible. To the extent that the lawyer can use an ADR program to achieve such client goals, he will have a satisfied client. And all of us know that the best form of lawyer advertising is a group of satisfied clients.

In deciding what to do about using ADR in a particular matter, the lawyer should always be on guard against irrational factors which will discourage his participation: ignorance, and unwillingness to learn; fear of seeming to be weak in suggesting ADR; the natural conservatism of the legal profession. Another negative factor which the responsible lawyer will guard against is his own psychological needs, e.g., to be a gladiator, to indulge his own needs for combat, even though client interests might call for a less adversarial approach, such as mediation. In short, "Lawyer, know thyself".

Finally, alternative dispute resolution offers the opportunity for the lawyer to be creative, to use his imagination in devising an ADR program suitable to the needs of the particular situation. For instance, there are special forms of arbitration, which limit the power of the arbitrator. An example, used in professional baseball salary arbitration, is "last best offer arbitration:" Another area where lawyers can be creative is in response to the familiar complaint about some arbitrators: they don't have the courage to make a clean decision, but simply compromise the competing claims. If you have this concern, but are locked into arbitration because of an arbitration provision in the underlying contract, draft against it in the submission to the arbitrator. Require the arbitrator to decide on the merits, even if it means that one side gets everything; prohibit a compromise decision, unless facts and law naturally lead to such a result.

\section{CONCLUSION}

My conclusion brings me back to the title of this talk: will the alternate dispute resolution movement be a mere flash in the pan, or the wave of the future? Right now, it is impossible to tell. Some supporters of ADR are enthusiastic about it; others are skeptical. My own view is that we simply don't have either the experience or the data to draw conclusions. I do suggest, if you are interested in pursuing this question further, that you read Prof. Hurlburt's 1986 speech to the Canadian Bar Association, entitled "Looking Backward: A Historical Review of Developments in the Litigation System from the Year 1986 to the Year 2000 A.D.' Prof. Hurlburt makes a shrewd analysis of what critics in the year 2000 might say about ADR, and about the litigation system.

I do remain hopeful that some forms of ADR will provide answers to the perennial problem of balancing the various, and competing goals, of a 
sound system of dispute resolution. The price of perfect justice may be too high, but we ought to be able to obtain an acceptable degree of justice, at reasonable cost and without unreasonable delay, for at least some disputants.

In that search for ADR mechanisms that work, I urge all of you judges, law teachers, practicing lawyers, and lawyers-about-to-be - to participate with genuine enthusiasm and with discriminating judgment. 